\title{
NOTES ON THE GADWALL AT KAZAN LAKE, SASKATCHEWAN
}

By the late THOMAS E. RANDALL.

Arriving at Kazan Lake, some 35 miles north of lle-a-la-Crosse on 24 June 1942 , my first impression was that I had come to a veritable "duck's paradise."

Wherever one looked, the water was dotted with ducks; some in compact masses, enjoying a mid-day siesta, thousands more in looser formations, the surface feeders incessantly tipping for food, the divers going to the bottom in rapid dives, surfacing only long enough to replace the air supply in their lungs. I was at once interested in tabulating the various species and was agreeably surprised that Gadwall were present in unexpected numbers. It at once occurred to me that Kazan Lake was probably at, or near, the northern breeding limits of this duck, and my explorations of the following weeks tended to confirm this impression. On a fairly large lake lying some 15 miles west of Kazan Lake, I saw 15 pairs of Gadwall but on the great Peter Pond Lake, some 20 miles to the north, the Gadwall was present in very samll numbers. At Ile-a-la-Crosse the Gadwall was very scarce, but the-odd pair or two could be found in some of the small deep inlets. I never saw Gadwall in the wide waters of the open lake. Realizing that this northerly breeding ground of the Gadwall was probably unknown to Canadian ornithologists, I paid special attention to this species and was well rewarded.

The first Gadwall nest was discovered on 9 June, a hollow scratched in the soil under a gooseberry bush growing on the low shore of an island some 30 feet back from the water's edge. It contained two eggs. The "scrape" was very scantily lined with dry grass and weed stems, this material forming a ring around the outer circumference of the hollow, with the two eggs actually lying on bare earth. The female flushed from the nest as I walked by and settled on the water about 75 yards away, where she was quickly joined by two males. For the next 5 minutes a good deal of chasing and bickering occurred which only ended when one male flew away down the lake. This sort of rivalry occurred on several occasions during the egg-laying and egg incubation period.

Each day one egg was added to the nest until 11 were deposited. As egglaying progressed, new material was added to the nest. When it held 11 eggs, it was a fairly bulky mass of dry vegetation mixed with a good supply of down and there was ample covering to protect the eggs when the duck was absent.

Egg-laying was suspended on the 12 th day but the final egg was added to the clutch on the 14 th day. The duck stayed

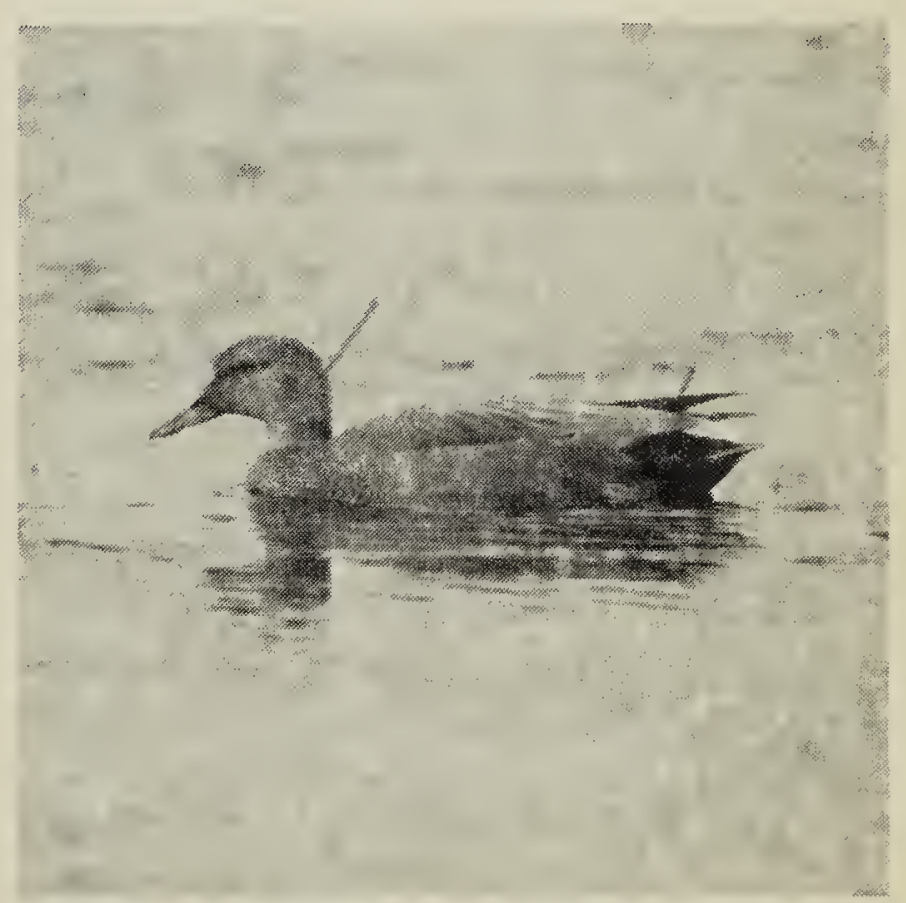

Gadwall

Lorne Scott 
on the nest during these two days except on three occasions when I flushed her from the nest. Then she immediately returned to the nest, once when I stood only 20 yards away.

Thirty-five days from the laying of the first egg I found the eggs were all "pipped" except two. Unfortunately a severe storm prevented an examination of the nest on the thirty-sixth day, but on the following day I found only one egg in the nest and that egg contained a dead embryo. I calculated the incubation period at 22-23 days.

\section{Nesting}

For nesting purposes the Gadwall does not approve of the tall bush, neither does it like open grassland. At Kazan Lake I found many nests a few yards back from the water's edge around the low rim of the islands. A fairly strong growth of grass with an occasional dwarf bush to add extra cover, appears to be the Gadwall's ideal nesting quarters. On the prairies of southern Alberta and Saskatchewan the landscape is dotted with large and small clumps of buck-brush and briers, and the Gadwall takes full advantage of this excellent cover.

At Kazan Lake, three islands terminated in a narrow point. Here the mucky soil was honey-combed with muskrat runs and walking was quite treacherous. A dense cover of nettles and semi-aquatic weeds covered these long points and the Gadwall found the covering greatly to their liking. The three points held 4,5 and 7 nests respectively, together with one White-winged Scoter, 5 Redhead and 5 Lesser Scaup nests.

In all, 38 Gadwall nests were found at Kazan Lake, only one of which was on the mainland. The largest clutch was 16 and the smallest incubated clutch was 5 eggs. The latter was found on 29 July and was probably a second laying.

Three nests were parasitized by the Redhead, with 1, 3 and 5 eggs being laid in the respective nests. While I have found a great deal of Redhead parasitism in the nests of other ducks on the prairies of Southern Alberta, it was not unduly prevalent at Kazan Lake and when it did occur, the Lesser Scaup was the usual victim. I could discover only one cause for this. Along the east side of the lake were scattered areas of Phragmites, the favourite nesting places of the Redhead, Mallard and Lesser Scaup. Here only one Gadwall nest was found, under a dwarf willow bush growing on the edge of the reeds. Thus is was only on the three nettle-covered points previously mentioned that Gadwall and Redhead nested together.

\section{Alberta Notes:}

Gadwall numbers fluctuated greatly in Southern Alberta. They were plentiful in 1919-20, then decreased rapidly until 1927 when they reached such a low point that I found only one nest containing nine eggs. It was 1936 before I saw another Gadwall nest, but by 1940 the species had recovered to become fairly numerous once again. It is noteworthy that the Green-winged Teal also suffered a great loss of numbers during the same period.

In Southern Alberta, I have seen as many as nine Redhead eggs with nine Gadwall eggs. The Gadwall, Canvasback and Lesser Scaup are the three species which successfully hatched Redhead eggs.

In 1944, while banding ducks for Ducks Unlimited, I trapped a female Mallard with six full-grown ducklings which were almost certainly MallardGadwall hybrids. The beak and legs were typical of the Gadwall, while the plumage of the upper back showed a strong diffusion of reddish-brown and four of the ducklings showed a trace of the rustcoloured patch on the shoulder of the wings.

EDITORS NOTE: We wish to thank Mrs. Barbara $M$. Jensen of Calgary for supplying her late father's manuscript. 